\title{
PENERAPAN METODE DEMONSTRASI DALAM MENUMBUHKAN KEAKTIFAN SISWA PADA PEMBELAJARAN FIKIH KELAS X SMA MUHAMMADIYAH O8 CERME
}

\author{
Bahaudin Mudhori \\ Aslich Maulana \\ Universitas Muhammadiyah Gresik \\ E-mail: mudhoribahaudin@gmail.com
}

\begin{abstract}
Abstrak: Penggunaan metode pembelajaran yang kurang efektif saat pembelajaran fikih, menjadi faktor penyebab kurang aktifnya pembelajaran yang dilakukan dikelas. Oleh karena itu penggunaan metode yang tepat akan menjadi salah satu faktor berhasilnya guru dalam melakukan proses pembelajaran, penggunaan metode yang tepat juga bisa membuat pembelajaran menjadi menyenangkan dan membuat siswa bisa secara aktif terlibat dalam pembelajaran di Kelas. Tujuan dari penelitian ini yaitu untuk mengetahui penerapan metode demonstrasi dalam menumbuhkan keaktifan siswa pada pembelajaran fikih dan juga untuk mengetahui hambatan dan pendukung dalam metode demonstrasi. Metode penelitian ini menggunakan pendekatan kualitatif. Pengambilan data pada penelitian ini dilakukan dengan cara observasi, wawancara serta dokumentasi yang bersumber dari guru dan juga siswa SMA Muhammadiyah 08 Cerme. Dari hasil penelitian yang telah dilakukan, menunjukkan bahwa dengan diterapkannya metode demonstrasi saat pembelajaran, siswa menjadi aktif dan pembelajaran di kelas lebih hidup. Adapun faktor yang mendorong untuk berhasilnya metode demonstrasi yang pertama siswa yang aktif memperhatikan, kedua materi pembelajaran yang bersifat praktik dan yang ketiga penggunaan kurikulum K13. Adapun faktor yang menjadi penghambat dalam pelaksanaan metode demonstrasi adalah siswa yang kurang memperhatikan, dan juga perlunya persiapan yang matang baik dari segi peralatan dan tempat serta persiapan seorang guru dalam mengajar.
\end{abstract}

Kata Kunci: metode demonstrasi, keaktifan, pembelajaran fikih. 


\section{PENDAHULUAN}

$\mathrm{P}$ endidikan Agama Islam merupakan sebuah ilmu pendidikan yang menjadi pembelajaran bagi siswa disekolah, sekaligus menjadi fondasi bagi umat manusia yang sangat mendasar dan mempunyai peran yang sangat besar bagi hidup dan kehidupan seluruh umat Islam. Pendidikan Agama Islam mengajarkan banyak nilai-nilai kehidupan yang bersumber dari Al-Qur'an dan Sunnah Rasulullah Muhammad SAW, kepada generasi umat Islam yang akan datang, sehingga diperlukan pembelajaran kepada seseorang yang menempuh sebuah proses pendidikan.

Salah satu mata pelajaran Pendidikan Agama Islam yang menjadi ciri khas adalah mata pelajaran fikih yang mana pada pelajaran tersebut dikembangkan melalui kegiatan siswa untuk memahami, meyakini, menghayati dan mengamalkan ajaran agama Islam baik yang berupa ajaran ibadah maupun muamalah melalui kegiatan pengajaran, bimbingan dan latihan sebagai bekal dalam melanjutkan pada jenjang pendidikan tinggi.

Mempelajari fikih, bukan hanya sekedar teori saja, tetapi harus mengandung unsur teori dan praktik. Belajar fikih hakikatnya untuk diamalkan, apabila berisi suruhan atau perintah, maka harus dapat dilaksanakan, dan apabila bila berisi larangan, harus dapat ditinggalkan atau dijauhi. Mata pelajaran fikih pada setiap sub bahasannya membutuhkan praktik atau demonstrasi secara langsung. Pentingnya praktik secara langsung pada pembelajaran fikih, selain membuat siswa bagus akan aplikasinya juga secara tidak langsung akan membuat siswa untuk berusaha meningkatkan keberanian dan mentalnya di dalam mendemonstrasikan sebuah materi secara langsung

Realita yang terjadi kebanyakan pada saat pembelajaran fikih adalah guru kurang menerapkan metode demonstrasi tersebut. Sehingga yang terjadi pada siswa adalah siswa paham akan materi, tetapi kurang mampu dalam mempraktikkannya secara langsung. Berdasarkan observasi yang telah dilakukan di kelas 10 IPA 1 SMA Muhammadiyah 08 Cerme, ketika mencoba sebuah percobaan praktik Shalat, terlihat hampir setengah dari jumlah murid yang ada, shalatnya belum sempurna baik gerakan atau bacaannya. ${ }^{1}$

Hal itu juga berdampak kepada keaktifan siswa. Siswa dikatakan kurang aktif karena mereka merasa belum berani untuk mempraktikkan Shalat secara indi-

\footnotetext{
${ }^{1}$ Observasi pembelajaran di Kelas 10 IPA 1 SMA Muhammadiyah 08 Cerme, pada hari Jumat 02 November 2018.
} 
vidu, dan belum mampu mempraktikkan Shalat dengan benar.

Berdasarkan masalah yang telah diuraikan di atas, maka dalam penelitian ini, memiliki dua masalah penelitian yang akan dibahas, yaitu: Bagaimana penerapan metode demonstrasi dalam menumbuhkan keaktifan siswa pada pembelajaran fikih? serta Apa saja hambatan dan pendukung dalam metode demonstrasi?.

Adapun tujuan yang akan dicapai pada penelitian kali ini adalah: untuk mengetahui sebuah proses penerapan metode pembelajaran demonstrasi yang akan bisa menumbuhkan keaktifan pada diri siswa dan mengetahui faktor yang menjadi penghambat serta pendukung dalam pelaksanaan metode demonstrasi.

\section{KERANGKA TEORI}

\section{Pengertian Metode Demonstrasi}

Ali al-Jumblaty dan Abu al-Fath Attawanisy mengartikan, metode sebagai cara-cara yang diikuti oleh guru yang menyampaikan maklumat ke otak muridmurid. $^{2}$

Rosdy Ruslan menerangkan bahwa metode merupakan kegiatan ilmiah yang berkaitan dengan suatu cara kerja (sistematis) untuk memahami suatu subjek atau objek penelitian, sebagai upaya untuk menemukan jawaban yang dapat dipertanggung jawabkan secara ilmiah dan termasuk keabsahannya. Jadi, dari beberapa keterangan yang diterangkan oleh para ahli tentang metode di atas, dapat disimpulkan bahwa metode merupakan suatu cara yang dilakukan oleh guru untuk memperlancar penyampaian informasi yang akan disampaikan kepada seorang murid, dengan menggunakan metode yang tepat, maka informasi yang disampaikan bisa dipahami dan bisa diterima dengan baik.

Selanjutnya adalah pengertian demonstrasi, Tayar Yusuf, Menjelaskan bahwa demonstrasi berasal dari kata demonstration (to slow) yang berarti memperagakan atau memperlihatkan proses kelangsungan sesuatu. $^{3}$

Pengertian metode demonstrasi menurut Syaiful Bahri Jamarah, metode demonstrasi adalah cara penyajian pelajaran dengan meragakan atau mempertunjukkan kepada siswa suatu proses, situasi, atau benda tertentu yang sedang dipelajari, baik sebenarnya ataupun tiruan, yang disertai dengan penjelasan lisan. ${ }^{4}$

\footnotetext{
${ }^{4}$ Syaiful Bahri Djamarah dan Aswan Zain, strategi belajar mengajar, (Jakarta: Rineka cipta, 2014) hlm. 90
} 
Oleh karena itu, dapat disimpulkan dari beberapa penjelasan para ahli di atas bahwa metode demonstrasi merupakan sebuah metode pembelajaran yang lebih menekankan ke peragaan atau praktik baik berupa kejadian, aturan, dan urutan melakukan suatu kegiatan yang ada baik secara langsung maupun menggunakan media yang relevan dengan pokok bahasan atau materi pembelajaran.

\section{Kelebihan dan Kekurangan Metode}

\section{Demonstrasi}

\section{a. Kelebihan}

Dalam proses belajar-mengajar, Penggunaan metode Demonstrasi memiliki arti penting. Banyak keuntungan yang bisa didapat baik secara psikologis-pedagogis yang dapat diraih dengan menggunakan metode demonstrasi. Berikut ini kelebihan yang sekaligus menjadi faktor pendukung dalam penggunaan metode demonstrasi.

Menurut Muhibbin Syah yaitu:

1. Perhatian siswa lebih dipusatkan.

2. Proses belajar siswa lebih terarah pada materi yang sedang dipelajari.

\footnotetext{
${ }^{5}$ Wina Sanjaya, strategi pembelajaran berorientasi standar proses Pendidikan, (Jakarta: Prenada media group, 2016), hlm. 152
}

3. Pengalaman dan kesan sebagai hasil pembelajaran lebih melekat dalam diri siswa.

b. Kekurangan.

Berikut ini merupakan kekurangan yang sekaligus menjadi faktor penghambat dalam penggunaan metode demonstrasi. Menurut Sanjaya W. Kekurangan metode demonstrasi adalah:

1. Metode demonstrasi memerlukan persiapan yang lebih matang, sebab tanpa persiapan yang memadai demonstrasi bisa gagal sehingga dapat menyebabkan metode ini tidak efektif lagi.

2. Demonstrasi memerlukan peralatan, bahan-bahan, dan tempat yang memadai yang berarti menggunakan metode ini memerlukan pembiayaan yang lebih mahal dibandingkan dengan ceramah.

3. Demonstrasi memerlukan kemampuan dan keterampilan guru yang khusus, sehingga guru dituntut untuk bekerja lebih profesional.. ${ }^{5}$

Menurut Zuhairi kelemahan metode demonstrasi adalah sebagai berikut: ${ }^{6}$ Dalam pelaksanaannya, biasanya memerlukan waktu yang relatif banyak atau panjang. Apabila tidak ditunjang dengan peralatan dan

\footnotetext{
${ }^{6}$ Zuhairini, dkk, Metodik Khusus Pendidikan Agama, (Malang FAK. Tarbiyah IAIN Sunan Ampel, 2001), hlm. 298
} 
Bahaudin Mudhori \& Aslich Maulana - Penerapan Metode Demonstrasi...

perlengkapan yang memadai atau tidak sesuai dengan kebutuhan maka metode ini kurang efektif. Metode ini sulit dilaksanakan apabila anak belum matang untuk mengadakan percobaan atau eksperimen. Banyak hal-hal yang tidak dapat didemonstrasikan yang dicobakan dalam kelas, demikian juga halnya dengan pendidikan agama

Melihat dari beberapa kelemahankelemahan yang ada di atas sebaiknya guru mengarahkan demonstrasi itu sedemikian rupa sehingga siswa bisa memperoleh pengertian dan gambaran yang benar tentang apa saja yang sedang didemonstrasikan dan sebaiknya sebelum demonstrasi itu dimulai, guru telah mengadakan uji coba supaya pelaksanaannya bisa dilakukan secara tepat.

\section{Menumbuhkan Keaktifan Siswa}

Menumbuhkan berasal dari kata dasar yaitu tumbuh yang kemudian mendapat imbuhan dari Me- dan -Kan. Dalam KBBI, Tumbuh didefinisikan sebagai timbul atau hidup dan bertambah besar atau sempurna. ${ }^{7}$ Keaktifan yang dimaksud dalam penelitian ini adalah keaktifan belajar siswa dikelas. Menurut kamus besar Bahasa Indonesia, aktif adalah giat (bekerja, berusaha), sedangkan keaktifan adalah suatu keadaan

\footnotetext{
${ }^{7}$ Kamus Q. "Tumbuh Pertumbuhan I Adalah Pengertian". Diakses dari https://www. kamusq.com/2012/11/tumbuh-pertumbuhanadalah-pengertian.html. Pada hari Rabu 17 April pukul 08.00.
}

atau hal di mana siswa aktif. Belajar adalah proses perubahan tingkah laku ke arah yang lebih baik dan relatif tetap, serta ditunjukkan dalam berbagai bentuk seperti berubahnya pengetahuan, pemahaman, sikap, tingkah laku, ketrampilan, kecakapan, kebiasaan, serta adanya perubahan aspek-aspek lain yang ada pada individu yang belajar.

Keaktifan belajar siswa dapat dilihat dari keterlibatan siswa dalam proses belajar mengajar yang beraneka ragam seperti saat mendengarkan penjelasan guru, diskusi, membuat laporan pelaksanaan tugas dan sebagainya.

Menurut Ahmadi dan Widodo Suproyono dalam buku karangannya menuliskan bahwa Siswa aktif adalah siswa yang terlibat secara intelektual dan emosional dalam kegiatan belajar. ${ }^{8}$ Keaktifan siswa dalam proses pembelajaran tidak hanya keterlibatan dalam bentuk fisik seperti duduk melingkar, mengerjakan/melakukan sesuatu, akan tetapi dapat juga dalam bentuk proses analisis, analogi, komparasi, penghayatan, yang ke semuanya merupakan keterlibatan siswa dalam hal psikis dan emosi. ${ }^{9}$

\footnotetext{
8 Abu Ahmadi \& Widodo Supriyono, Psikologi Belajar, (Jakarta: Rineka Cipta, 2004), hlm. 207

9 Achmad sugandi, Teori Pembelajaran, (Semarang: UNNES Press, 2004), hlm 75
} 


\section{Ciri-ciri Keaktifan Siswa}

Untuk melihat terwujudnya keaktifan siswa dalam proses belajar mengajar terdapat beberapa indikator cara belajar siswa aktif. Melalui indikator cara belajar siswa aktif dapat dilihat tingkah laku mana yang muncul dalam suatu proses belajar mengajar. Indikator tersebut yaitu:

1. Keinginan, keberanian menampilkan minat, kebutuhan dan permasalahannya.

2. Keinginan dan keberanian serta kesempatan untuk berpartisipasi dalam kegiatan persiapan, proses dan kelanjutan belajar.

3. Penampilan berbagai usaha/ kekreatifan belajar mengajar sampai mencapai keberhasilannya

4. Kebebasan melakukan hal tersebut tanpa tekanan guru/ pihak lainnya ${ }^{10}$

Keaktifan siswa tampak dalam kegiatan, antara lain: berbuat sesuatu untuk memahami materi pelajaran dengan penuh keyakinan, mempelajari, mengalami dan menemukan sendiri bagaimana memperoleh situasi pengetahuan, merasakan sendiri bagaimana tugas-tugas yang diberikan oleh guru kepadanya, belajar dalam kelompok,

\footnotetext{
${ }^{10}$ Abu Ahmadi \& Widodo Supriyono, Op. Cit., hlm. 208

11 Suryosubroto, Proses Belajar Mengajar Di Sekolah, (Jakarta: Rineka Cipta, 2002) hlm. 71
}

mencoba sendiri konsep-konsep tertentu, dan mengkomunikasikan hasil pikiran, penemuan, dan penghayatan nilai-nilai secara lisan atau penampilan ${ }^{11}$

Penelitian ini mengadaptasi dan memodifikasi dari pendapat Ahmadi dan Suryosubroto tentang ciri-ciri tentang keaktifan siswa yang nantinya akan menjadi tolok ukur dalam penilaian peningkatan keaktifan siswa

\section{Pengertian Pembelajaran}

Menurut Hamalik Pembelajaran adalah suatu kombinasi yang tersusun meliputi unsur-unsur manusiawi, material, fasilitas, perlengkapan, dan prosedur yang saling mempengaruhi mencapai tujuan pembela$\operatorname{jaran}^{12}$

Menurut Cagne dan Biggs pembelajaran adalah rangkaian peristiwa yang mempengaruhi siswa sedemikian rupa sehingga proses belajarnya dapat berlangsung dengan mudah, dengan tujuan membantu siswa atau orang untuk belajar. ${ }^{13}$

Dari beberapa pengertian di atas, maka dapat disimpulkan bahwa yang dimaksud pembelajaran adalah kegiatan yang dilakukan secara sadar oleh guru untuk

12 Oemar Hamalik, Kurikulum Dan Pembelajaran, (Jakarta: Bumi Aksara, 2015), Cet.15, hlm. 57

13 Tengku Zahara Djaafar. Kontribusi Strategi Pembelajaran Terhadap Hasil Belajar.(Jakarta : Universitas Negeri Padang.2001) 
melaksanakan kegiatan belajar yang di dalamnya terdapat proses transfer ilmu dari seorang guru kepada siswa.

\section{Pengertian Fikih}

Fikih adalah bahasa Arab dalam bentuk masdar dari kata faquhayahqahu. Kata fikih semula berarti al-'ilmu (pengetahuan) dan al-fahmu (pemahaman). Jadi fikih menurut bahasa berarti: "mengerti, paham dan pintar". ${ }^{14}$ fikih secara etimologis berarti: "paham yang mendalam."

Menurut Syaikh Islam Abi Yahya Zakariya bin Al Anshory, fikih menurut bahasa adalah paham, sedangkan menurut istilah adalah ilmu tentang hukum syariah amaliah yang diperoleh dari dalil-dalil yang terperinci. Sementara itu ulama-ulama lain mengemukakan fikih adalah Ilmu tentang hukum syariah amaliah yang diperoleh melalui jalan ijtihad.

Menurut Hatib Rachmawan, Secara bahasa kata fikih dapat diartikan al-Ilm, artinya ilmu, dan al-fahm, artinya pemahaman. Jadi fikih dapat diartikan sebagai ilmu yang mendalam. Jika Secara istilah, fikih diartikan sebagai ilmu yang menerangkan tentang hukum-hukum syar ${ }^{\mathrm{ec}} \mathrm{i}$ yang berkaitan dengan perbuatan-perbuatan yang

\footnotetext{
${ }^{14}$ Yunus Mahmud, Kamus Arab Indonesia, (Jakarta: PT Hidakarya Agung, 1990), hlm. 321
}

dilakukan para mukalaf yang dikeluarkan dari dalil-dalilnya yang terperinci.

Berdasarkan penjelasan berbagai ahli di atas, peneliti dapat menyimpulkan bahwa fikih merupakan sebuah pengetahuan yang dalam pelaksanaannya harus sesuai dengan hukum-hukum syariat Islam, dengan dalidalil yang secara rinci mengenai perbuatan yang hubungannya terkait dengan amaliah manusia.

\section{Tujuan Pembelajaran Fikih}

Tujuan dari pembelajaran fikih adalah menerapkan aturan-aturan atau hukumhukum syariah untuk dijalankan dalam kehidupan. Sedangkan tujuan dari penerapan aturan-aturan itu adalah supaya manusia terdidik dan agar memiliki sikap, karakter takwa dan menciptakan kemaslahatan bagi manusia.

\section{Ruang lingkup Pembelajaran Fikih}

Mata pelajaran Fikih adalah sebuah bagian dari pelajaran agama di sekolah yang mempunyai ciri khas jika dibandingkan dengan pelajaran yang lainnya, mata pelajaran fikih mempunyai ciri khas karena pada pelajaran tersebut terdapat tanggung jawab untuk dapat memberikan motivasi dan kompensasi sebagai manusia yang mampu 
mengamalkan dan memahami hukum Islam yang berkaitan dengan ibadah mahdhoh serta muamalah dan dapat mempraktikkannya secara benar di kehidupan sehari-hari.

Fikih berisi tentang sebuah aturanaturan yang sangat rinci berdasarkan petunjuk dari Allah untuk dilakukan oleh umat manusia, maka dapat disimpulkan bahwa fikih secara garis besar memuat dua hal pokok. Pertama, tentang apa yang diwajibkan Allah untuk langsung beribadah kepada-Nya dan kedua bakti kepada Allah melalui baktinya kepada sesama manusia. Adapun hal-hal yang dilakukan dari hambanya untuk beribadah kepada Allah adalah seperti perintah untuk berpuasa pada surat Al-Baqarah ayat 183:

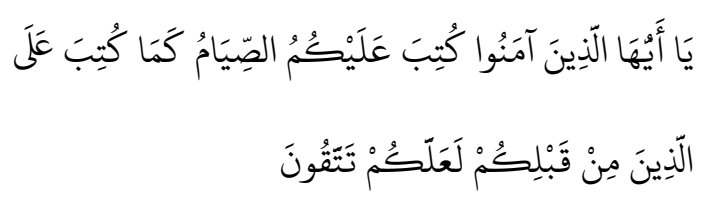

Artinya: "Hai orang-orang yang beriman, diwajibkan atas kamu berpuasa sebagaimana diwajibkan atas orang-orang sebelum kalian agar kamu bertakwa". ${ }^{15}$

Ada juga perintah untuk mengerjakan Shalat, dijelaskan pada Qs. Al-Baqarah: 43:

$$
\text { وَأَقِيمُوا الصَّلَاةَ وَاتُتُوا الزَّكَاةَ وَارْكَُوا مَعَ الََّاكِعِينَ }
$$

15 Kementerian Agama RI. Syaamil Al-Qur'an Miracle The Reference.Op.Cit hlm 53.

16 Kementerian Agama RI. Syaamil Al-Qur'an Miracle The Reference. Ibid, hlm.11
Artinya: Dan dirikanlah Shalat, tunaikanlah zakat dan rukulah bersama orangorang yang ruku. ${ }^{16}$

Ibadah Shalat merupakan ibadah yang paling utama yang harus dikerjakan oleh umat manusia sebagai hamba Allah SWT. Shalat dalam agama Islam menepati kedudukan yang paling utama yang akan dipertanggung jawabkan. Shalat merupakan tiang agama, yang mana apabila orang Islam tidak mendirikan Shalat, maka mereka telah merobohkan Islam itu sendiri. Selain sebagai tiang agama yang dapat menjadi tolak ukur tegak atau kokoknya keimanan seseorang juga sebagai bekal kita di akhirat kelak karena shalat merupakan amalan pertama kali yang akan dihisab, serta shalat merupakan penyembahan langsung terhadap Allah dengan kata lain bila kita ingin dekat dengan-Nya dan berinteraksi langsung yaitu dengan cara shalat. Kita diperintahkan shalat dengan benar, sesuai tata cara yang telah diajarkan oleh Nabi Muhammad saw, beliau bersabda:

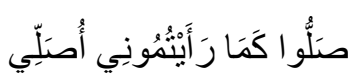

"Shalatlah kamu sebagaimana kamu melihatku shalat." [HR. Bukhari]. ${ }^{17}$

Pentingnya pembelajaran Shalat pada siswa merupakan hal yang sangat wajib.

17 Dr. Raehanul Bahraen. Pelajari tatacara Shalat dengan benar. Diakses dari https://muslim.or.id/ 45578-pelajari-tata-cara-shalat-denganbenar.html. Pada tanggal 23 Juni 2019, pukul $11.10 \mathrm{WIB}$ 
karena apabila siswa tidak tahu akan cara Shalat yang benar, maka shalatnya menjadi tidak sah. Pentingnya sebuah praktik Shalat dalam pembelajaran dengan menggunakan metode pembelajaran yang tepat, maka siswa akan lebih mudah bisa dalam menerapkannya.

\section{METODOLOGI PENELITIAN}

Penelitian yang berjudul "Penerapan Metode Demonstrasi, Dalam Menumbuhkan Keaktifan Siswa, Pada Pembelajaran Fiqih Kelas 10 SMA Muhammadiyah 08 Gresik”. Peneliti bermaksud untuk mengkaji lebih dalam metode demonstrasi pembelajaran fikih Bab Shalat dengan Menggunakan pendekatan kualitatif.

Adapun sumber data yang digunakan untuk penelitian ini yaitu terdiri dari 2 data yaitu data primer dan data sekunder. Teknik pengambilan data pada penelitian ini berupa observasi, wawancara, dan dokumentasi.

Proses analisis dalam penelitian ini menggunakan empat komponen yang utama, yaitu, pengumpulan data, reduksi data, penyajian data dan terakhir verifikasi atau kesimpulan.
HASIL PENELITIAN DAN PEMBAHASAN

\section{Penerapan Metode Demonstrasi dalam Menumbuhkan Keaktifan Siswa Pada Pembelajaran Fikih}

Pada pembelajaran Pendidikan Agama Islam khususnya pembelajaran mata pelajaran fikih, di dalam mata pelajaran fikih pada setiap sub babnya selalu ada materi yang bersifat amaliah, artinya seorang siswa harus bisa mempraktikkannya dalam kehidupan sehari-hari dengan benar sesuai yang di contohkan oleh Rasulullah Muhammad SAW, sehingga diperlukan langkah yang dilakukan oleh seorang guru untuk memilih metode pembelajaran yang tepat saat mengajar mata pelajaran fikih tersebut.

Pada saat pembelajaran juga wajib bagi anak-anak untuk aktif dalam melihat mendengarkan dan mengamati setiap hal yang dilakukan oleh guru, oleh karena itu guru selalu menggunakan sebuah metode yang tepat saat mengajar, seperti yang dilakukan oleh Bapak Lukman, beliau menggunakan metode demonstrasi agar membuat kelas menjadi aktif, adapun pelaksanaan penerapan metode demonstrasi agar bisa menumbuhkan keaktifan seorang siswa adalah : ${ }^{18}$

18 Wawancara dengan Bapak Lukman tanggal 12 April 2019. Kantor SMAM 08 Cerme. 
Pertama, Guru menyusun bahan ajar sesuai materi yang akan diajarkan dan siswa menyiapkan sumber belajar yang akan digunakan saat pembelajaran. Penting bagi seorang guru sebelum memulai pembelajaran untuk menyiapkan bahan ajar yang akan disampaikan kepada murid, karena dengan persiapan yang matang, maka akan menghasilkan pembelajaran yang baik pula.

Kedua, mendiskusikan bahan materi belajar dengan membuat kelompok kecil. Tujuan dilakukannya berdiskusi dengan kelompok kecil adalah agar memberikan stimulus bagi siswa sebelum dimulainya pembelajaran bersama seorang guru. Pemberian aktivitas kepada siswa sebelum dimulainya pembelajaran memang baik dilakukan. Salah satunya yaitu bisa dilakukan dengan cara berdiskusi, dengan cara berdiskusi siswa menjadi aktif dan saling terlibat dalam saling bertukar informasi dengan kelompoknya.

Ketiga, dengan melibatkan siswa untuk melihat, mendengar dan mengawasi praktik yang dilakukan seorang guru untuk ditirukan oleh siswa, sehingga siswa menjadi aktif secara psikisnya. Keaktifan Psikis ini meliputi keaktifan indera dalam melakukan kegiatan belajar. Dengan melaksanakan proses demonstrasi atau memberikan cara melalui praktik kepada siswa, maka siswa akan terlibat aktif dalam proses melihat, mendengar dan mengawasi aktivitas tersebut. bentuk keaktifan psikis salah satunya yaitu berupa keaktifan indra manusia, mulai dari melihat, mendengar dan mengawasi setiap tindakan yang dilakukan seorang oleh guru di depan kelas.

Keempat, memberikan rangsangan dan motivasi kepada siswa, memberikan rasa untuk percaya diri dan dorongan semangat sehingga nanti akan muncul dalam diri siswa reaksi belajar yang bisa membuat siswa akan lebih percaya diri, dan berani saat akan melakukan sesuatu. Fungsi seorang guru tidak hanya sebagai Pengajar saja, tetapi harus bisa sebagai mediator yang bisa mentransfer ilmu dengan cara yang baik dan juga sebagai seorang motivator yang selalu bisa memberikan semangat kepada siswasiswanya agar senantiasa semangat dalam pelaksanaan pembelajaran di dalam kelas.

Melaksanakan pembelajaran Shalat memang efektif dengan menggunakan metode demonstrasi, karena Shalat memang tidak bisa dilakukan secara sembarangan. Sehingga menuntut siswa agar bisa secara benar dalam melakukan ibadah Shalat dalam kehidupan sehari-hari. Dan dengan penggunaan metode demonstrasi pada pembelajaran fikih pada bab Shalat dapat membuat siswa menjadi lebih aktif saat pembelajaran dikelas. Berdasarkan observasi selanjutnya yang dilakukan oleh peneliti, terjadi perubahan pada keaktifan siswa, siswa terlibat 
secara intelektual, emosional serta keaktifan secara fisik untuk mempraktikkan Shalat. ${ }^{19}$

Sebagaimana yang diungkapkan oleh bapak Lukman, beliau mengungkapkan bahwa: "Memang terjadi perubahan yang sangat signifikan yang terjadi pada siswa setelah dilakukannya metode tersebut, yaitu anak-anak menjadi bisa mempraktikkan Shalat sesuai tuntunan Rasulullah dan suasana dalam kelas menjadi sangat aktif". ${ }^{20}$

Dari Analisis di atas, dapat peneliti simpulkan bahwa dengan menggunakan metode demonstrasi pada pembelajaran fikih bab shalat dapat menumbuhkan keaktifan seorang siswa saat pembelajaran.

\section{Pendukung dan Hambatan dalam Metode Demonstrasi.}

Dalam melaksanakan sebuah metode saat terjadi pembelajaran tentu saja ada faktor-faktor yang menjadi mendukung dan menjadi penghambat.

Faktor pertama yang menjadi pendorong suksesnya penggunaan metode demonstrasi adalah Siswa. Berdasarkan wawancara yang dilakukan dengan Bapak Lukman selaku Guru PAI pada tanggal 16 April 2019, beliau mengungkapkan bahwa:

\footnotetext{
${ }^{19}$ Observasi saat pembelajaran Fiqih di kelas XI pada tanggal 12 April 2019.

${ }^{20}$ Wawancara dengan bapak Lukman pada tanggal 12 April 2019 di Kantor SMA Muhammadiyah 08 Cerme.
}

"Banyak hal yang menjadi faktor pendorong pelaksanaan metode demonstrasi agar bisa berjalan dengan baik, yang pertama yaitu dari diri siswa sendiri. Pelaksanaan metode demonstrasi akan mudah dilakukan apabila siswa bisa fokus kepada hal-hal yang dilakukan oleh guru, apabila perhatian siswa hanya terfokus kepada guru maka proses pelaksanaannya akan jadi lebih mudah". ${ }^{21}$

Faktor kedua yaitu materi pembelajaran, pada pembelajaran fikih bab Shalat kali ini memang tepat menggunakan metode demonstrasi, karena di situ terdapat praktikpraktik untuk mengerjakan Shalat secara benar sesuai ajaran Rasulullah Muhammad SAW.

Berdasarkan wawancara selanjutnya dengan Bapak Lukman, beliau mengungkapkan bahwa: "Materi pembelajaran yang menekankan kepada siswa untuk bisa mempraktikkan Shalat secara benar, sehingga dengan menggunakan metode ini proses belajar siswa lebih terarah pada materi yang sedang dipelajari, dan dapat membimbing siswa ke arah berpikir yang sama dalam satu saluran pikiran yang sama, ${ }^{22}$

Faktor pendukung berikutnya yaitu penggunaan Kurikulum K13 di lembaga

\footnotetext{
${ }^{21}$ Wawancara dengan Bapak Lukman pada tanggal 16 April 2019 di Kantor SMA Muhammadiyah 08 Cerme.

${ }^{22}$ Wawancara dengan Bapak Lukman pada tanggal 16 April 2019 di Kantor SMA Muhammadiyah 08 Cerme.
} 
tersebut, seperti yang diungkapkan oleh Bapak Lukman bahwa: "Faktor yang menjadi pendukung metode demonstrasi yang terakhir yaitu dari kurikulum K13, yang mana kurikulum ini lebih menekankan pada pembelajaran aktif yang dilakukan oleh seorang siswa."23

Seorang siswa menjadi faktor yang paling menentukan untuk sukses atau tidaknya penggunaan metode pembelajaran. Siswa di dalam kelas mempunyai karakter yang berbeda-beda sehingga terkadang seorang guru pun juga terkadang kesulitan untuk mengajak siswa tersebut agar bisa aktif dan fokus saat pembelajaran. Ketika observasi di dalam kelas masih terlihat ada satu atau dua anak yang tidak semangat dalam pembelajaran. ${ }^{24}$

Sebagaimana yang diungkapkan oleh Bapak Lukman saat wawancara bahwa: "Yang menjadi penghambat juga bisa datang dari diri seorang siswa. Apabila siswa kurang semangat dalam pembelajaran, maka akan sulit untuk diajak aktif, karena mereka harus mempraktikkan Shalat dengan benar yang melibatkan keaktifan secara fisik. Sehingga terkadang saya juga memberikan penyegaran kepada anak-anak seperti game

\footnotetext{
${ }^{23}$ Wawancara dengan Bapak Lukman pada tanggal 16 April 2019 di Kantor SMA Muhammadiyah 08 Cerme.

${ }^{24}$ Observasi saat pembelajaran Fiqih di kelas X pada tanggal 12 April 2019.
}

dan lain-lain agar mereka semangat kembali. $^{25}$

Dari wawancara di atas, menjelaskan bahwa pelaksanaan pembelajaran bisa berjalan dengan baik apabila semua siswa mendengarkan, serta mengikuti arahanarahan yang dilakukan oleh seorang guru.

Berikutnya yang menjadi faktor penghambat yaitu metode demonstrasi sendiri yang memerlukan persiapan yang matang baik dari segi peralatan tempat ataupun persiapan dari seorang guru sendiri ${ }^{26}$

Hal ini sesuai yang dijelaskan oleh Wina Sanjaya bahwa yang menjadi faktor penghambat dari metode demonstrasi adalah persiapan yang lebih matang, baik dari peralatan bahan-bahan dan tempat yang memadai, selain itu juga dari gurunya sendiri yang harus bekerja lebih profesional. ${ }^{27}$

Dari keterangan di atas menjelaskan bahwa yang menjadi faktor penghambat dalam pelaksanaan metode demonstrasi yang pertama yaitu siswa, kedua yaitu metode demonstrasi yang memerlukan persiapan yang lebih matang baik dari segi peralatan tempat dan dari persiapan seorang guru sendiri tersebut.

\footnotetext{
${ }^{25}$ Wawancara dengan Bapak Lukman pada tanggal 16 April 2019.di Kantor SMA Muhammadiyah 08 Cerme.

26 Hasil Wawancara Dengan Bapak Lukman pada tanggal 16 April 2019.di Kantor SMA Muhammadiyah 08 Cerme.

${ }^{27}$ Wina Sanjaya, Op.Cit.,hlm. 152
} 
Bahaudin Mudhori \& Aslich Maulana - Penerapan Metode Demonstrasi...

\section{KESIMPULAN}

1. Penerapan metode demonstrasi dalam menumbuhkan keaktifan siswa pada pembelajaran fikih. Berdasarkan uraian hasil penelitian yang telah dikembangkan di bab sebelumnya, maka dapat disimpulkan bahwa Penerapan metode demonstrasi dalam menumbuhkan keaktifan siswa pada pembelajaran fikih kelas 10 SMA Muhammadiyah Cerme dilakukan dengan cara: Pertama, Guru menyusun bahan ajar sesuai materi yang akan diajarkan dan siswa menyiapkan sumber belajar yang akan digunakan saat pembelajaran. Kedua, mendiskusikan bahan materi belajar dengan membuat kelompok kecil. Tujuan dilakukannya berdiskusi dengan kelompok kecil adalah agar memberikan stimulus bagi siswa sebelum dimulainya pembelajaran bersama seorang guru. Ketiga, yaitu melibatkan siswa untuk melihat, mendengar dan mengawasi praktik yang dilakukan seorang guru untuk ditirukan oleh siswa, sehingga siswa menjadi aktif secara psikisnya. Keempat, yaitu memberikan rang-sangan dan motivasi kepada siswa, memberikan rasa untuk percaya diri dan dorongan semangat sehingga nanti akan muncul dalam diri siswa reaksi belajar yang bisa membuat siswa akan lebih percaya diri, dan berani saat akan melakukan sesuatu.

Dari empat cara yang dilakukan tersebut dapat menumbuhkan keaktifan siswa pada pembelajaran fikih pada bab Shalat saat di kelas.

2. Penghambat dan Pendukung metode demonstrasi. Dalam proses pelaksanaan metode pembelajaran demonstrasi terdapat beberapa hal yang menjadi faktor penghambat sekaligus pendukung dalam pembelajaran. Faktor Penghambat: (1) Faktor penghambat bisa datang dari Kondisi siswa yang kurang semangat, (2) Perlunya persiapan yang matang baik dari segi peralatan dan tempat serta persiapan seorang guru dalam mengajar. Faktor Pendukung: (1) Keadaan siswa yang mendukung selama pembelajaran sedang berlangsung, Materi Pembelajaran Fiqih Bab Shalat yang mendukung untuk menggunakan metode demonstrasi, (3) Penggunaan kurikulum K13 yang menekankan pada keaktifan siswa dalam pembelajaran

\section{DAFTAR PUSTAKA}

Ahmadi, Abu, Widodo Supriyono. 2004. Psikologi Belajar. Jakarta: Rineka Cipta

Djamarah, S.B, Aswan Zain. 2014. Strategi Belajar Mengajar. Jakarta: Rineka cipta.

Hamalik, Oemar. 2015. Kurikulum dan Pembelajaran. Jakarta: Bumi Aksara. https://muslim.or.id/45578-pelajari-tatacara-shalat-dengan-benar.html 
https://www.kamusq.com/2012/11/tumbuhpertumbuhan-adalah-pengertian.html

Kementerian Agama RI. 2010 .Syaamil AlQur'an Miracle The Reference. Bandung: Sygma Publishing.

Mahmud, Yunus. 1990. Kamus Arab Indonesia. Jakarta: PT Hidakarya Agung.

Mulyasa, E. 2003. Kurikulum Berbasis Kompetensi. Bandung: Remaja Rosdakarya.

Rofi'i, Ahmad. 2009. Pembelajaran Fiqih, Jakarta: Direktorat Jenderal Pendidikan Islam Departemen Agama RI.

Rosyadi, Khoiron. 2004. Pendidikan Profetik, Yogyakarta : Pustaka Pelajar.
Sanjaya, Wina. 2016. Strategi Pembelajaran Berorientasi Standar Proses Pendidikan. Jakarta: Prenada media group.

Subroto, Suryo. 2002. Proses Belajar Mengajar Di Sekolah. Jakarta: Rineka Cipta.

Yusuf Tayar, dkk. 2000. Metodologi Pengajaran Agama dan Bahasa Arab, Jakarta: Raja Grafindo.

Zahara Djaafar, Tengku. 2001. Kontribusi Strategi Pembelajaran Terhadap Hasil Belajar. Jakarta: Universitas Negeri Padang.

Zuhairini, dkk, 2010. Metodik Khusus Pendidikan Agama, (Malang FAK. Tarbiyah IAIN Sunan Ampel. 